\title{
PENGARUH MODEL PEMBELAJARAN KONTEKSTUAL TERHADAP KETERAMPILAN MENULIS PANTUN PADA SISWA KELAS XI SMA SWASTA PERSIAPAN STABAT TAHUN PEMBELAJARAN 2018/2019
}

\author{
Melsa Alfiani ${ }^{1}$, Juwita Erdani, M.Hum ${ }^{2}$, Sanimah, M. Pd ${ }^{3}$ \\ STKIP Budidaya Binjai
}

\begin{abstract}
ABSTRAK
Tujuan penelitian ini adalah untuk mengetahui pengaruh model pembelajaran kontekstual terhadap keterampilan menulis pantun melibatkan dua variabel yaitu Variabel bebas (X) dan Variabel terikat (Y). Penelitian ini dilakukan di SMA Swasta Persiapan Stabat. Desain penelitian yang digunakan dalam penelitian ini adalah nonequivalent control design. Teknik pengambilan sampel menggunakan cluster random sampling. Instrumen yang digunakan untuk mengumpulkan data pada penelitian ini adalah tes uraian sebanyak 5 soal yang sesuai dengan indikator keterampilan menulis pantun. Hasil penelitian menunjukkan bahwa rata-rata keterampilan menulis pantun siswa yang diajarkan dengan model pembelajaran kontekstual sebesar 79,77, sedangkan rata-rata nilai kelompok kontrol sebesar 78,60. Dari hasil uji hipotesis diperoleh nilai $t_{\text {hitung }}>t_{\text {tabel }}$ yaitu 2,78 $>1,98$, maka hipotesis yang menyatakan keterampilan menulis pantun yang dalam pembelajarannya menggunakan pembelajaran kontekstual lebih tinggi bila dibandingkan dengan model pembelajaran konvensional pada mata pelajaran bahasa Indonesia di SMA Swasta Persiapan Stabat diterima.

kata kunci : model pembelajaran kontekstual, menulis, pantun
\end{abstract}

\section{PENDAHULUAN}

Keterampilan berbahasa Indonesia yang dalam pembelajaran bahasa Indonesia meliputi empat jenis keterampilan, yakni menyimak, berbicara, membaca, dan menulis. Berdasarkan aktivitas penggunaannya, keterampilan membaca dan menyimak tergolong keterampilan berbahasa yang bersifat reseptif, letak perbedaannya adalah terdapat pada sarana yang dipergunakan yaitu bunyi dan tulisan, berbicara dan menulis, termasuk keterampilan berbahasa yang bersifat produktif, yaitu secara lisan dan secara tertulis.

Keterampilan menulis merupakan salah satu aspek kemampuan dalam berbahasa mengungkapkan ide, gagasan (pendapat) siswa berupa tulisan, dan menulis erat hubungannya dengan proses pembelajaran yang dialami siswa selama menuntut 


\section{Jurnal Serunai Bahasa Indonesia \\ Vol.16, No.1, Februari 2019 \\ e-ISSN 2621-5616}

ilmu di sekolah. Sedangkan menulis ditujukan untuk meningkatkan apresiasi siswa. Kegiatan mengapresiasikan berkaitan erat dengan latihan mempertajam perasaan, penalaran, dan daya khayal, serta kepekaan terhadap masyarakat, budaya dan lingkungan hidup. Salah satu cara mengembangkan apresiasi sastra kepada siswa adalah pengajaran pantun, dengan tujuan agar siswa memperoleh kesadaran yang lebih terhadap dirinya sendiri, orang lain, dan lingkungan sekitar, memperoleh kenangan, memperoleh pengetahuan, dan pengertian dasar tentang pantun yang perlu mendapat perhatian dan pengajaran pantun disekolah adalah pemilihan bahan pengajaran dan penyajiannya.

Pantun adalah bentuk puisi lama yang terdiri dari empat larik, menulis pantun membutuhkan proses kreatif yang tidak dapat dicapai secara praktis. Oleh karena itu dibutuhkan pengetahuan tentang pantun agar siswa lebih mudah dalam menulis pantun. Untuk mampu menulis sebuah pantun perlu adanya pemikiran cara menentukan sampiran dan isi pantun.

Beberapa hal yang merupakan permasalahan dalam menulis pantun yang dialami siswa kelas XI SMA Persiapan Stabat, diantaranya ; (1) kurang mendorong siswa untuk aktif, karena masih menggunakan model pembelajaran yang konvensional, sehingga kemandiriannya, cara penemuan terhadap topik permasalahan juga kurang, dan tidak bisa mengkontrusi pengetahuannya dengan keterampilan baru, sehingga sifat ingin tahunya lemah, (2), jarang melakukan pembelajaran dengan model diskusi kelompok, (3) terbatasnya pengusaan kosa kata yang dimiliki siswa, (4) cara merefleksi pembelajaran masih didominasi guru.

Melalui penelitian ini, penulis ingin meningkatkan kemampuan keterampilan menulis pantun, yaitu melalui penggunaan media gambar. Penggunaan Model pembelajaran kontekstual ini sebagai alternatif pembelajaran menulis pantun sehingga diharapkan siswa akan lebih tertarik untuk menuangkan ide atau gagasan dalam bentuk tulisan dan diharapkan dapat mengurangi kejenuhan siswa dalam pembelajaran menulis. Berdasarkan uraian pada latar belakang di atas, maka penulis mengangkat judul "Pengaruh Model Pembelajaran Kontekstual Terhadap 
Jurnal Serunai Bahasa Indonesia

Vol.16, No.1, Februari 2019

e-ISSN 2621-5616

Keterampilan Menulis Pantun Pada Siswa Kelas XI SMA Swasta Persiapan Stabat Tahun Pembelajaran 2018/2019”.

\section{METODE}

Penelitian ini menggunakan metode penelitian eksperimen semu (Quasi Experiment), yang menggunakan desain penelitian "non-equivalent control group design", secara keseluruhan populasi penelitian berjumlah 251 siswa kelas XI SMA Persiapan Stabat. Sampel sebanyak 88 siswa terdiri dari dua kelas, diperoleh melalui teknik random sampling terhadap delapan kelas. Selanjutnya sampel secara random di bagi menjadi 2 kelompok sesuai dengan kelas, kelompok kontrol dan kelompok eksperimen. Kedua kelompok ini layak sebagai sampel setelah terbukti setara melalui uji t dua sisi. Variabel dalam penelitian ini yaitu Variabel bebas dan terikat. Data keterampilan menulis dikumpulkan dengan tes keterampilan menulis dengan kisi-kisi tes. Sebelum instrumen digunakan, terlebih dahulu dilakukan soal pretest kemudian diberikan treatment dan ketika murid sudah paham akan pembeljaran akan diberikan posttes. Penghitungan menggunakan uji normalitas, homogenitas dan uji hipotesis.

Data hasil penelitian dianalisa secara bertahap, tahapan-tahapan tersebut adalah deskripsi data, uji prasyarat dan uji hipotesis. Uji prasyarat yang dilakukan adalah uji normalitas data dengan menggunakan Liliefors, uji homogenitas Lilefors, jika uji prasyarat sudah terpenuhi maka dapat dilanjutkan dengan uji hipotesis dengan menggunakan uji t.

\section{HASIL PENELITIAN DAN PEMBAHASAN}

Berdasarkan uji normalitas data, diperoleh hasil bahwa semua data yaitu hasil model pembelajaran kontekstual dalam keterampilan menulis siswa baik dikelompok eksperimen maupun kelompok kontrol berdistribusi normal dengan harga dari kelompok eksperimen $\mathrm{L}_{\text {hitung }}>\mathrm{L}_{\text {tabel }}$ yaitu 0,182 >0,132, ini membuktikan bahwa data variabel $\mathrm{X}$ berdistribusi normal, dan kelompok kontrol $\mathrm{L}_{\text {hitung }}>\mathrm{L}_{\text {tabel }}$ yaitu 0,168 $>0,135$, ini membuktikan bahwa data variabel Y berdistribusi normal. Sedangkan 


\section{Jurnal Serunai Bahasa Indonesia \\ Vol.16, No.1, Februari 2019 \\ e-ISSN 2621-5616}

untuk pengujian homogenitas menggunakan diperoleh untuk data kemampuan menulis signifikansi dengan $\mathrm{F}_{\text {hitung }}<\mathrm{F}_{\text {tabel }}$ yakni 1,06 $<1,66$ maka dapat disimpulkan sampel berasal dari kelompok homogen. Dari uji hipotesis pada perhitungan uji t-test diperoleh harga $t_{\text {hitung }}=2,78>t_{\text {tabel }} 1,98$, maka $\mathrm{H}_{\mathrm{o}}$ ditolak dan $\mathrm{H}_{\mathrm{a}}$ diterima. Artinya, rata-rata keterampilan menulis pantun dalam pembelajaran kontekstual kepada siswa kelas eksperimen lebih tinggi daripada kelas kontrol yang menggunakan metode konvensional.

Berdasarkan hal tersebut, semakin adanya suatu pendekatan pembelajaran yang langsung mengaitkan materi konteks pelajaran dengan pengalaman nyata dalam kehidupan sehari-hari. Pendekatan pembelajaran tersebut adalah pendekatan kontekstual atau Contextual Teaching and Learning (CTL). Pada pendekatan ini guru tidak mengharuskan siswa menghafalkan fakta-fakta tetapi guru hendaknya mendorong siswa untuk mengkonstruksi pengetahuan di benak mereka sendiri. Selain itu, guru juga harus berusaha membuat siswa ikut terlibat dalam pembelajaran. Dengan demikian, melalui pembelajaran CTL siswa diharapkan belajar melalui "mengalami" bukan menghafal. Pendekatan kontekstual akan menghasilkan siswa yang inovatif serta mempunyai kecakapan hidup (life skill). Oleh karena itu, pendekatan kontekstual memfokuskan siswa sebagai pebelajar yang aktif (student centered).

Pendekatan kontekstual atau Contextual Teaching and Learning (CTL) merupakan konsep belajar yang membantu guru mengaitkan antara materi yang diajarkan dengan situasi dunia nyata siswa dan mendorong siswa membuat hubungan kehidupan mereka sebagai anggota keluarga dan masyarakat. Dengan konsep ini, hasil pembelajaran diharapkan lebih bermakna bagi siswa. Pembelajaran kontekstual membutuhkan penilain yang jelas (Asesmen Autentik). Artinya, perlu disusun seperangkat evaluasi keterlaksanaan pembelajaran kontekstual, instrument serta teknik penilaian yang tepat. Untuk melihat keterlaksanaan pembelajaran kontekstual guru perlu mengetahui cara mengukur, menilai dan memutuskan apakah siswa telah bekerja sebagaimana yang diinginkan atau belum. Melalui alat ukur yang jelas guru 


\section{Jurnal Serunai Bahasa Indonesia \\ Vol.16, No.1, Februari 2019 \\ e-ISSN 2621-5616}

akan mudah mengetahui apakah siswa benar-benar telah menguasai materi pembelajaran, kurang menguasai atau tidak menguasai sama sekali. Salah satu bentuk alat ukur atau penilaian dalam pendekatan pembelajaran kontekstual adalah penilaian/asesmen autentik. Pembelajaran kontektual akan lebih berpengaruh terhadap peningkatan kemampuan menulis siswa karena siswa bisa mengaitkan materi yang diajarkan guru dengan situasi dunia nyata yang dialami siswa melalui menulis.

Dengan meningkatnya kemampuan menulis, maka pada akhirnya akan bermuara pada meningkatnya hasil belajar bahasa Inggris peserta. Sedangkan model pembelajaran konvensional merupakan proses pembelajaran yang cenderung berpusat pada guru. Dalam merancang dan mengimplementasikan program pembelajaran, guru tidak memperhatikan kemampuan awal (prior knowledge) yang dimiliki siswa. Proses pembelajaran berlangsung satu arah, peran guru tidak lagi sebagal fasilitator dan mediator yang baik melainkan guru memegang otoritas pembelajaran. Proses pembelajaran seperti ini menciptakan situasi belajar mengajar yang pasif. Siswa cenderung hanya menuruti apa yang diperintahkan oleh guru sehingga kemampuannya untuk membangun dan menuangkan konsep-konsep yang akan ditulis menjadi berkurang. Situasi pembelajaran ini bertentangan dengan filosofi Kurikulum 2013, dimana orientasi pembelajaran semestinya terpusat pada aktifitas siswa dengan materi yang sesuai dengan karakteristik siswa, akibatnya kemampuan menulis siswa yang diajar dengan model pembelajaran konvensional akan cenderung kurang baik bila dibandingkan dengan kelompok siswa diajar dengan model kontekstual. Dengan kurang baiknya kemampuan menulis, maka hasil pembelajaran pantun pada siswa kelas XI SMA Swasta Perisapan Stabat juga akan menjadi tidak maksimal.

\section{SIMPULAN}

Pembelajaran kontekstual berpengaruh terhadap kemampuan menulis pantun siswa kelas XI SMA Swasta Persiapan Stabat. Mengacu kepada temuan penelitian 


\section{Jurnal Serunai Bahasa Indonesia \\ Vol.16, No.1, Februari 2019 \\ e-ISSN 2621-5616}

ini, dapat dikemukakan beberapa Saran, antara lain: Pertama, kepada para guru Bahasa Indonesia hendaknya perlu mempertimbangkan penggunaan model pembelajaran kontekstual sebagai model alternative dalam aktivitas pembelajaran dikelas untuk dapat meningkatkan hasil belajar menulis pantun dan ketrampilan menulis siswa. Karena penggunaan model pembelajaran kontekstual telah terbukti dan mampu dalam meningkatkan ketrampilan menulis dan hasil belajar menulis pantun siswa dibandingkan dengan model evaluasi konvensional. Kedua, Kepada siswa agar selalu belajar aktif dan menemukan sendiri pengetahuan dengan memanfaatkan berbagai sumber pembelajaran yang diberi guru. Kepada kepala sekolah untuk lebih memperhatikan dan melengkapi fasilitas yang dapat memperlancar proses belajar mengajar. Selain itu, untuk pihak-pihak yang berwenang menangani bidang pendidikan, agar melatih terlebih dahulu guru-guru tentang model pembelajaran kontekstual sebelum mereka diminta mengaplikasikan dalam pembelajaran. Dengan jalan demikian, diharapkan guru telah terbiasa menggunakan model pembelajaran kontekstual dalam pembelajaran.

\section{REFERENSI}

Departemen Pendidikan. 2000. Kamus Besar Bahasa Indonesia Edisi Ketiga. Jakarta : Balai Pustaka.

Depdiknas, 2003. Pendekatan Kontekstual (Contextual Teaching and Learning (CTL). Jakarta : Depdiknas

Eko, Sugiarto. 2012. Pantun dan Puisi Lama Melayu. Yogyakarta: Kithah Publishing.

Hernowo. 2003. Quantum Writing Cara Cepat nan Bermanfaat untuk Merangsang Munculnya Potensi Menulis. Bandung: Mizan Learning Center.

Joko, Santoso. 2013. Buku pintar Pantun, Puisi Lama Melayu dan Peribahasa Indonesia. Yogyakarta: Araska.

Moenir, A.S. 2008. Manajemen Pelayanan Umum di Indonesia. (akarta: Bumi Aksara. 
Jurnal Serunai Bahasa Indonesia

Vol.16, No.1, Februari 2019

e-ISSN 2621-5616

Nadjua A.S. 2005. Intisari Kata Bahasa Indonesia, Surabaya : Triana Media, tanpa tahun.

Paulo Freire. 1987. Cara Menjadikan Anak Bergairah Menulis. Bandung : Kaifa

Rani. 1996. Pembelajaran Sastra yang Apresiatif dan Integaratif di Sekolah dasar. Jakarta: Departemen Pendidikan Nasioanal

Sanjaya, Wina. 2005. Pembelajaran dalam Implementasi Kurikulum Berbasis Kompetensi. Jakarta : Prenada Media

Sudjana. 2002. Metode Statistika. Bandung : Tarsito.

Yunus, Suparno Mohammad. 2009. Keterampilan Dasar Menulis. Jakarta: Universitas Terbuka. 